\title{
Impact of passive cooling techniques on the thermal behavior of residential buildings in hot and arid regions -An experimental study-
}

\author{
Athmani $\mathrm{W}^{1, *}$, Sriti $\mathrm{L}^{2}$
}

1 PhD student, LACOMOFA Laboratory, College of Architecture, Mohamed Khidher University, P.0 Box: 145 RP 07000 Biskra - Algeria

2 Professor, LACOMOFA Laboratory, College of Architecture, Mohamed Khidher University, P.0 Box: 145 RP 07000 Biskra - Algeria.

* Corresponding Author: athmani.wafa@gmail.com

Received: 05-02-2018

Revised: 14-04-2018

Accepted: 19-04-2018

\begin{abstract}
The thermal performance of the roof is one of the most important factors for a comfortable environment. As $50 \%$ of the thermal loads received by a building come from the roof, this research seeks to find the roofing system that opposes the transmission of heat during the hottest days and promotes indoor thermal comfort. In this regard, this paper presents an experimental study carried out on four (04) testing cells constructed on a reduced scale and submitted to climatic external conditions. Three (03) cells were used to test passive cooling strategies through the roof, namely: the cool roof, ventilated roof and a roof with inverted earth pots. The fourth cell that served as cell-reference, for its part, a conventional roof. The experimentation concerned the types of roofs most used in residential buildings in Biskra, Algeria. The measurements process was effectuated in an exposed field during the month of July, prevailing the metrological data of the hot and arid climate. The obtained results show that the use of the cool-roof technique makes it possible to record the lowest internal temperatures in comparison with the other systems. Thus, the reflective coating technique is capable of reducing the internal temperature from $3.33^{\circ} \mathrm{C}$ to $4.80^{\circ} \mathrm{C}$, also the internal and external surface temperature of the roofs from $5.31^{\circ} \mathrm{C}$ to 10.18 ${ }^{\circ} \mathrm{C}$, respectively. These experimental results confirm the effectiveness of the "cool roof" technique as an innovative and efficient solution that contributes to the achievement of the comfort conditions in a hot and arid climate by eliminating heat gains through the roof.
\end{abstract}

Key words: Passive cooling, cool roof, thermal performance, scale-model testing, residential buildings.

\section{Introduction}

In hot and arid environments where climatic conditions are extreme, the thermal performance of buildings has become a curricular issue for designers, researchers, and occupants. However, in this type of regions, the excessive exposure of the building envelope to intense solar radiation is considered to be the major cause of the thermal discomfort felt in spaces (Bencheikh, 2013). In this situation, the absence of building envelope that is climatically efficient, urges the occupant to seek, constantly, an improvement of their accommodations comfort by the use of mechanical cooling systems for longer periods of time.

In recent decades, we attend in Algeria a large urban extension and a production of energyconsuming constructions that are indifferent to the climate. Today, the residential sector in Algeria accounts for $40 \%$ of total electricity consumption.

The building envelope such as the interface between the interior of the building and the outdoor environment serve as a thermal barrier. It plays an important role in determining the amount of energy needed to maintain a comfortable indoor environment relative to the external environment (Madhumathi et al., 2014). As the horizontal element of the envelope, the roof is the most exposed to solar radiation; it receives sunlight for almost the entire day, which makes it responsible for $50 \%$ of the total heat gain in buildings (Dabaieh et al, 2015). 
the undesirable storage of thermal energy through the roof is an important issue in desert regions where cement-based materials are commonly used in building constructions (Nahar et al., 1999). Moreover, this horizontal element of the envelope offers an important potential for passive cooling because of its large surface exposed to the sky. (Santamouris et al., 2001, Akbari et al., 2005).

Passive cooling roof systems play an important role in dissipating heat and thermal gains during the warm season and maintain the indoor air temperature close to the comfort zone (18$27^{\circ} \mathrm{C}$ ) at the same time, it is inexpensive, simple to operate and the materials are available in the trade (Charde et al., 2013). Givoni (1978) defines passive cooling as a strategy based on a sustainable approach to cool buildings by natural means. This strategy involves controlling the heat exchange with the environment in order to offer a lower ambient temperature than the outside and a low energy consumption. On this matter, a large number of studies in the scientific literature have largely dealt with the influence of passive roof cooling techniques on the thermal and energy performance of residential spaces. These techniques concern, in particular, passive cooling: by evaporation (Tiwari et al., 1994; Raeissi and Theri, 2000), by radiation "cool roof" (Gentle et al., 2011; Kolkotroni et al., 2013; Lee et al., 2008) and by shading roof (Madhumathi et al., 2014).

\section{Purpose of work}

The main objective of this paper is to study the impact of different passive cooling techniques applied on roofs (the reflective membrane, ventilated roof inverted earthen pots) and to examine the possibilities of their use on roofs of typical houses in the hot and arid climate of the city of Biskra. In this regard, an experimental study was envisaged by testing four (04) cells (scale models) constructed of concrete and submitted to real climatic conditions. For this experiment, it is about the evaluation of the three (03) techniques chosen, also, to demonstrate their advantage in minimizing the thermal stresses in buildings, implicitly, to reduce energy consumption and preserve the environment.

\section{Literature review: background}

The concept of "cool roof" is documented by numerous scientific researches and studies based on experimental analyses carried out on residential and nonresidential buildings.

Therefore, Synnefa et al. (2007) demonstrated that the cool roof surfaces remain cooler than traditional materials during summer conditions. This characteristic makes these roofs effective in improving the thermal performance of buildings, reducing energy consumption and providing superior environmental benefits compared to very insulated standard roofs (Bakhlah et al, 2012). For their part, Akbari et al. (2005) in their research on hot climates showed that increasing the solar reflectance of a roof from $0.2 \%$ to $0.6 \%$ can reduce $20 \%$ of cooling energy of buildings.

Nahar et al. (1999; 2003) realized a comparative study of four different techniques (1- reflective paint, 2- thermal insulation, 3- shallow ponds with movable thermal insulation, 4- evaporative cooling) used to improve the thermal performance of roofs. The experiment was made on five identical test structures measuring $120 \mathrm{~cm} \times 60 \mathrm{~cm} \times 90 \mathrm{~cm}$ in Jodhpur (India). They found that the reflective paint technique recorded a difference of $7^{\circ} \mathrm{C}$ compared to the prototype control. Nevertheless, the best results have been obtained for the evaporative cooling technique $\left(10^{\circ} \mathrm{C}\right)$, but this system requires a large quantity of water $50 \mathrm{ml} / \mathrm{m}^{2}$ per day (Fig. 1).

Another experimental study was conducted by Hamdan et al. (2012) involving several passive cooling techniques. Four structures measuring $0.6 \mathrm{~m} \times 1 \mathrm{~m} \times 1 \mathrm{~m}$ were tested during a summer day in Amman, Jordan. These techniques are as follows: 1- standard ceiling roof (concrete prototype) $8 \mathrm{~cm}$ thick, which is generally used in Jordan, 2-roof with white cement, 3- roof with broken pieces of white glazed, 4 - a roof covered with a layer of clay $(\mathrm{ep}=3 \mathrm{~cm})$. The researchers 
showed that structure four (04) was the best cooling potential recorded in the hot and arid climate of Amman.

Amer (2006) studied experimentally the effect of passive cooling techniques related to the roof, including 1-roof with white paint, 2- thermal insulation with a $5 \mathrm{~cm}$ layer of glass wool, 3roof with chimney solar, 4- evaporative cooling. In addition to a reference cell (a standard concrete roof); four (04) cells each one was equipped with a cooling system built in the warm and dry climate of Manouifia, Egypt. Through measurements of the indoor air temperature of each test cell, during a typical summer day, researchers showed that the average difference in air temperature between the passive test cells and the reference cell reached: $6.5^{\circ} \mathrm{C} ; 2$ to $7{ }^{\circ} \mathrm{C} ; 3$ to $8.5^{\circ} \mathrm{C}$ and 4 to $9.8^{\circ} \mathrm{C}$, respectively.

Lee et al. (2009) experimentally analyzed the effect of a ventilated and non-ventilated inclined roof on the energy and thermal performance of a prototype $(2.0 \mathrm{~m} \times 1.4 \mathrm{~m} \times 0.4 \mathrm{~m})$ with different cavity widths.

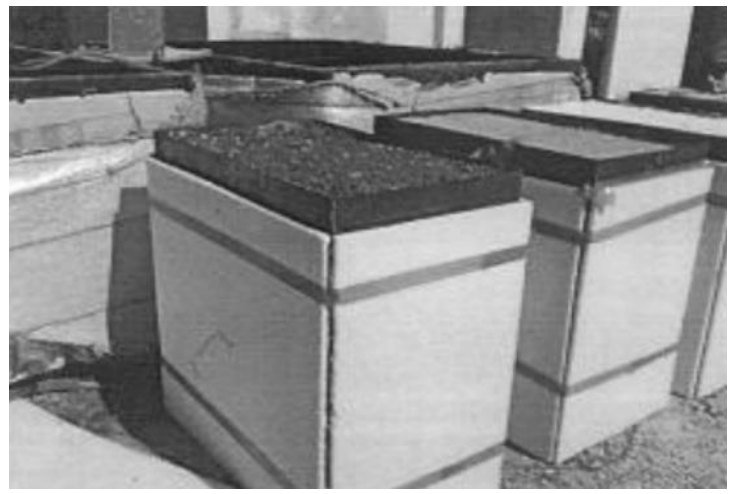

Fig 1. Passive test structures installed in the field

\section{Passive cooling roof techniques}

\subsection{Concept of the reflective roof: the "cool roof"}

According to Parker et al. (1995) "cool roof" is a passive technique based on a typology of construction that helps to reduce energy and thermal requirements from the building envelope. This technique is based on the ability of the roof to reflect solar radiation and to emit heat, which allows it to be cooler than a conventional roof (Pisello et al., 2013). On the other hand, Urban and Roth (2010) have shown that during hot days, when typical dark roof temperatures can reach $66^{\circ} \mathrm{C}$, a reflective roof is around $28^{\circ} \mathrm{C}$ (Al-Obaidi et al., 2014) (Fig.2).

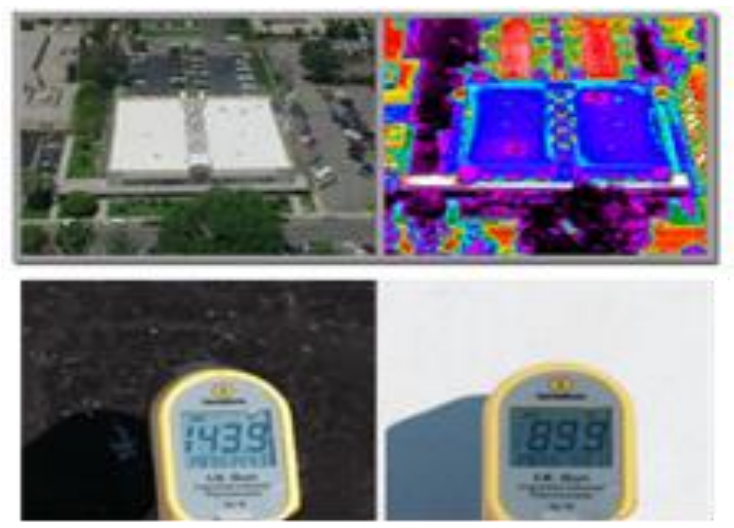

Fig 2. Temperature of dark surface VS temperature of cool roof

"Cool materials" are materials that do not significantly increase their surface temperature under solar radiation and minimize the absorption of sunlight. Conforming to Zinzi et al. (2010), high 
solar reflectance and thermal emissivity are two key properties that determine the temperature and degree of freshness of a roof:

1. Solar reflectance (SR): The High capacity to reflect the incident solar radiation on the material. The reflectivity varies from about 0.1 (black color) to 0.8 (white color).

2. Thermal emissivity $(\varepsilon)$ : The High capacity to radiate heat in infrared wavelengths. It is between 0.8 and 0.9 .

Therefore, several advantages are provided by the "cool roof" technology: on the urban scale, the reduction in the temperature of the outside air leads to the reduction in the amount of heat transmitted by the roofs to the urban environment (Zinzi et al., 2009; 2010). It is also possible to reduce the impact of the urban heat island phenomenon. At the building level, the "cool roof" improves the thermal comfort of spaces, limits the use of air conditioners and reduces the consumption of electricity (Pisello et al., 2013). It also helps extend the life of roofs.

\subsection{Ventilated roof}

In areas where solar radiation is high, the ventilation of construction structures minimizes the cooling load during the summer period and in fact reduces the energy requirements of buildings (Lee et al., 2009).

One of the advantages of ventilation is the reduction of the heat fluxes transmitted by the structures exposed to the solar radiation thanks to the combined effect of shading surfaces and heat evacuation by the air flow in the ventilated zone; the air flow in the cavity efficiently transports heat and moisture to the outside and maintains the temperature of the internal part of the roof (Balocco et al., 2002) (Fig.3).

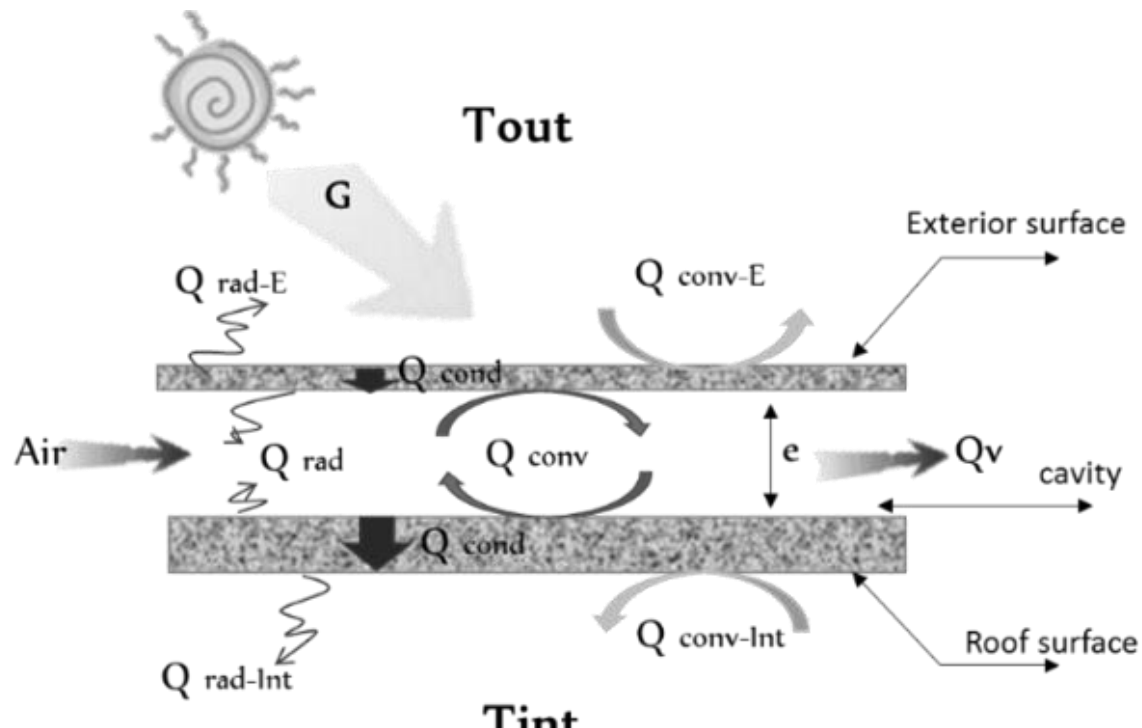

Fig.3. Mechanism of heat transfer in a ventilated roof

\subsection{Inverted earthen pot on roof (roof shading)}

A system used in traditional architecture, where, through empty earthen pots functioning as small air in inverted and arranged cavities on the surface of the roof. These pots are waterproof, and they act as a barrier to heat transfer, due to the microscopic porous structure of their surface (Fig.4). 


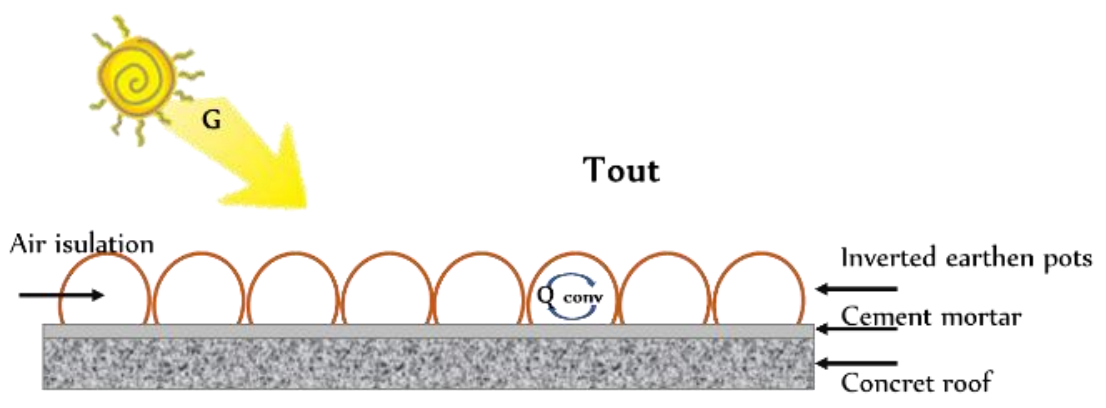

Tint

Fig.4. Schematic Section of Roof with inverted earthen pots Shading

\section{Methodology}

The main objective of this study is to evaluate the influence of the various passive cooling-roof techniques on the thermal comfort felt inside spaces. these techniques have been tested under the hot and arid climate conditions of Biskra, to define the most appropriate solutions to this region.

In order to achieve these objectives, four (04) test cells have been constructed with identical geometric and thermos-physical characteristics. Only the treatment of the roof is modified. So, the four prototypes of tests were realized on a reduced scale and subjected to the external conditions.

Three (03) cells were used to test passive cooling strategies through the roofs, specifically: cool roof, ventilated roof and a roof with inverted earthen pots. The fourth cell is served as a control structure which has a conventional roof.

\subsection{Main steps of experimental work}

The main steps of the research are described as follows:

1. Choice of the study case: a matrix has been developed regrouping the different types of roofs used in private residential constructions in Biskra.

2. Measurement period: The period of the experiment is fixed at the hottest month of the year, which corresponds to the month of "July".

3. The experimental framework: Include the choice of cell dimensions, choice of materials, and realization of the prototypes.

4. Measurement: temperatures were taken every 2 hours with instruments that measured surface temperatures at specific points.

\subsection{Choice of study corpus: typology of existing roofs}

The study is carried out on roofs of individual contemporary constructions in Biskra. Through an investigation, a corpus of houses was assembled and then a typo-morphological analysis of the roofs was accomplished.

The houses chosen for the study were selected on the basis of the most recurring physical characteristics, in particular building materials and exterior roofing treatments. We restricted our study to the flat roofs.

A matrix, showing the different roofs construction alternatives and their coatings, was developed (Table 1). 
Table 1 presents the matrix of the different types of roofs and the coding system developed for the purposes of the study.

After measuring of inside temperature of 12 houses, we found that TpRc has a maximum interior temperature $40.85{ }^{\circ} \mathrm{C}$, which means a situation of thermal discomfort for the occupants and a significant consumption of electrical energy.

Table 1. Coding system used to identify the roofs

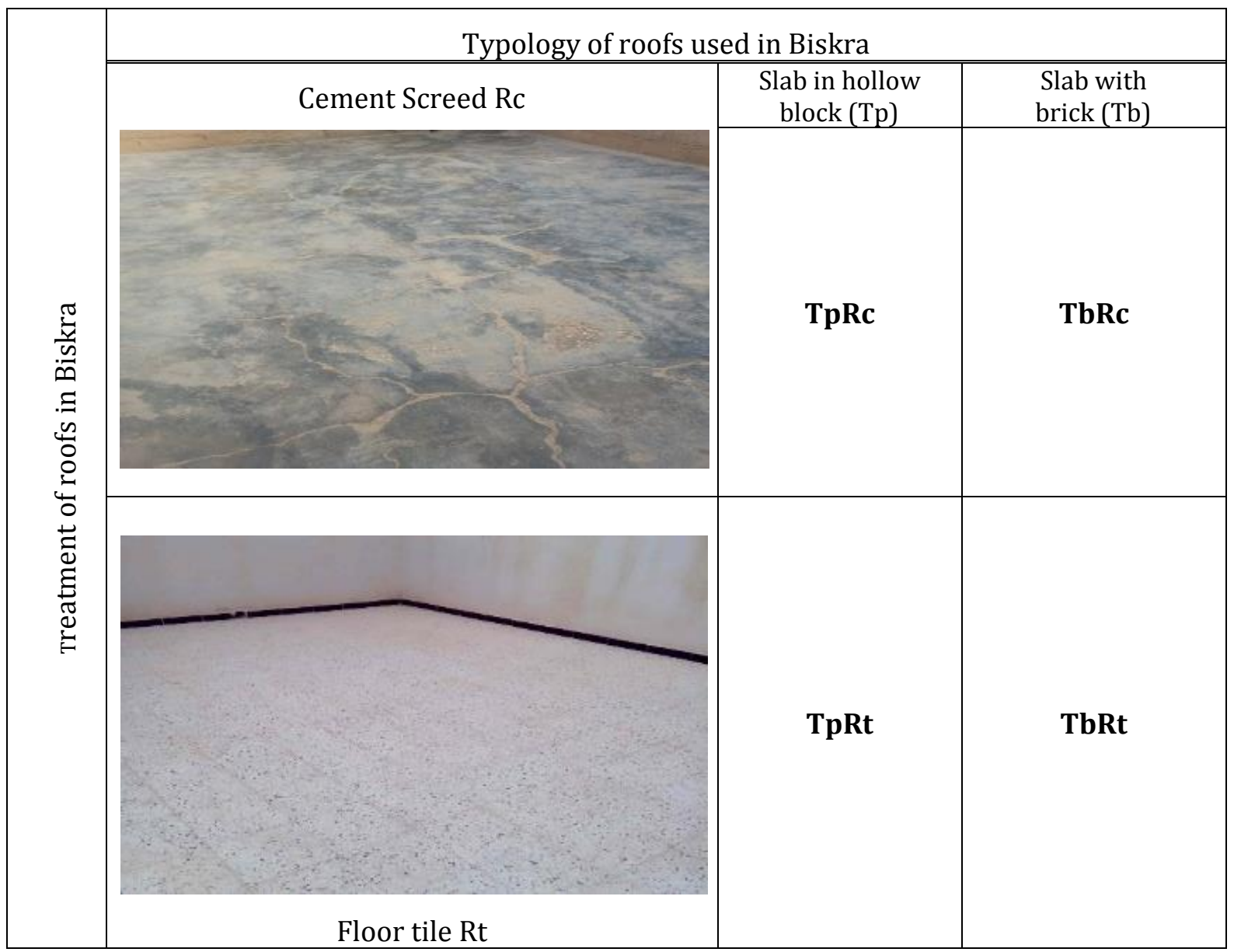

\subsection{Climatic analysis of Biskra}

The city of Biskra is located in the Southeast of Algeria. It is located in the northern part of the Sahara at a latitude of $34.8^{\circ} \mathrm{N}$, longitude $5.73^{\circ} \mathrm{E}$, and an altitude of $87 \mathrm{~m}$. Biskra belongs to a region classified aridly where predominates a hot and dry climate with cold winters and hot summers. The maximum temperature reaches $46^{\circ} \mathrm{C}$ during the month of July, and the minimum temperature falls to $13^{\circ} \mathrm{C}$ in winter during the month of January.

The average annual temperature is $37.3^{\circ} \mathrm{C}$, while the average annual humidity is around $40 \%$. Very low precipitation is recorded with a maximum of $20 \mathrm{~mm} /$ year. The directions of the prevailing winds are northwest in winter, south-east in summer at a speed of 4 to $10 \mathrm{~m} / \mathrm{s}$.

\subsection{Experimental Set-Up}

\subsubsection{Cells description}

In this study, the TpRc type is taken as a case study because it represents the worst case. On this topic, four (04) cells $(\mathrm{C} 1, \mathrm{C} 2, \mathrm{C} 3, \mathrm{C} 4)$ of $(1.20 \times 0.80 \mathrm{X} 1 \mathrm{~m})$ orienting along the East-West axis 
were built on a site in a dense urban area (old Biskra) which benefits all day long from the solar energy without any mask (Fig.5).

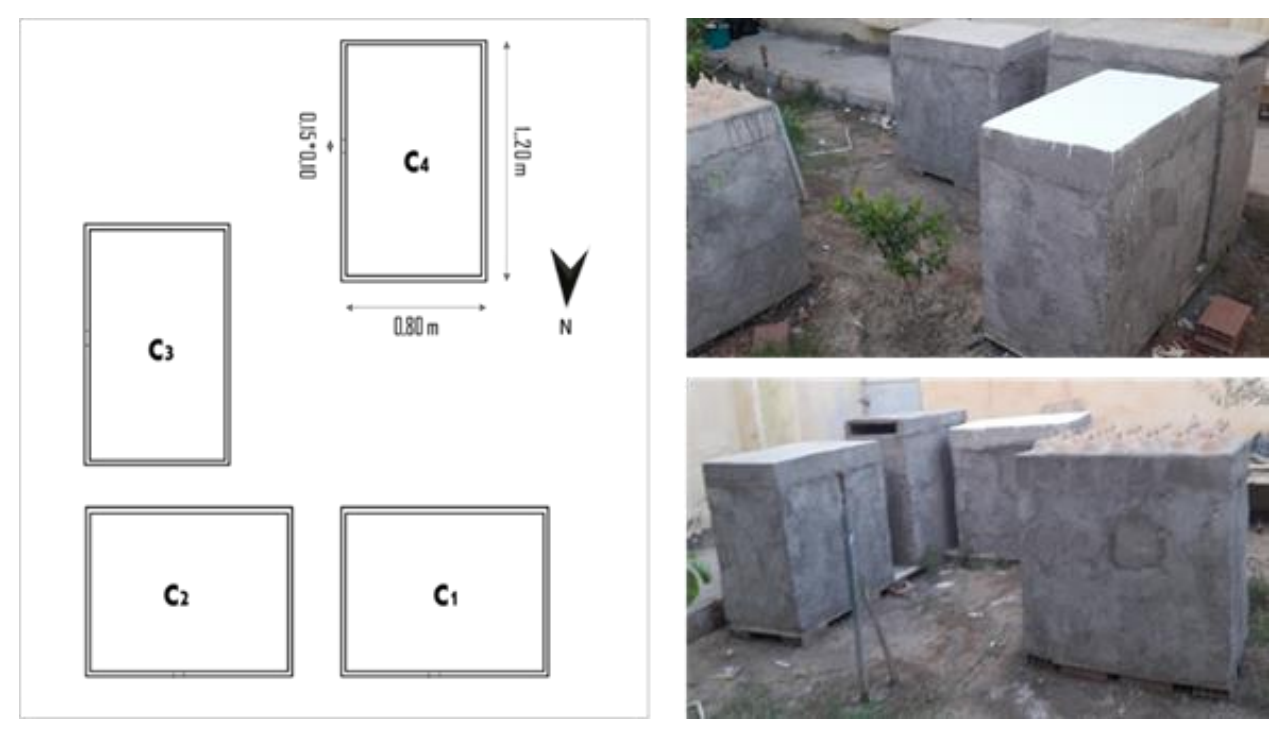

Fig.5. Experimentation: dimensions and disposition of cells

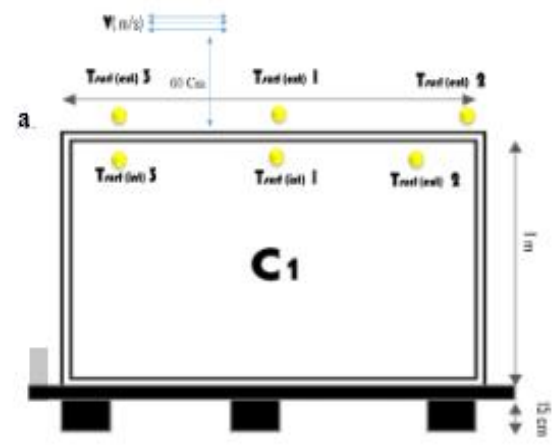

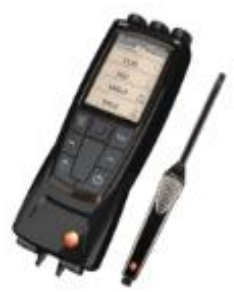

c

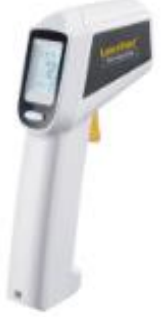

Fig.6. (a)The measurements points; (b) TESTO 480; (c) LAZER LINER THERMOSPOT

Independently from the treatment of the roof, the cells tested had the same dimensional and thermos-physical properties; the roofs were $20 \mathrm{~cm}$ thick, and the exterior walls were made of $10 \mathrm{~cm}$ hollow brick. The structures were coated with cement to limit air infiltration and thermal bridges.

An opening of $15 \mathrm{~cm} \times 10 \mathrm{~cm}$ covered with a polystyrene plate allows to open the cells at the time of the measurements and to record the surface temperature of the roof. The structures were raised on the ground by $15 \mathrm{~cm}$ on a wooden support.

- Cell 1 (C1): a structure without any treatment (reference case).

- Cell 2 (C2): ventilated roof with a $10 \mathrm{~cm}$ air cavity width.

- Cell 3 (C3): a roof with a reflective coating (PLANET SUPRA) which help to reduces the infrared (heat) consumptively; solar reflectance (SR) $=94.6 \%$, emittance $(\varepsilon)=0.90$.

- Cells 4 (C4): inverted earthen pots on the roof. The clay has a low thermal conductivity. 


\section{Results and discussion}

\subsection{Temperature profiles of exterior surface}

The experimentation was conducted under conditions of sunny sky. Figure 7 shows the surface temperature average (Ts) of the 4 test cells compared with the average surface temperature of reference case (control cell) measured in-situ.

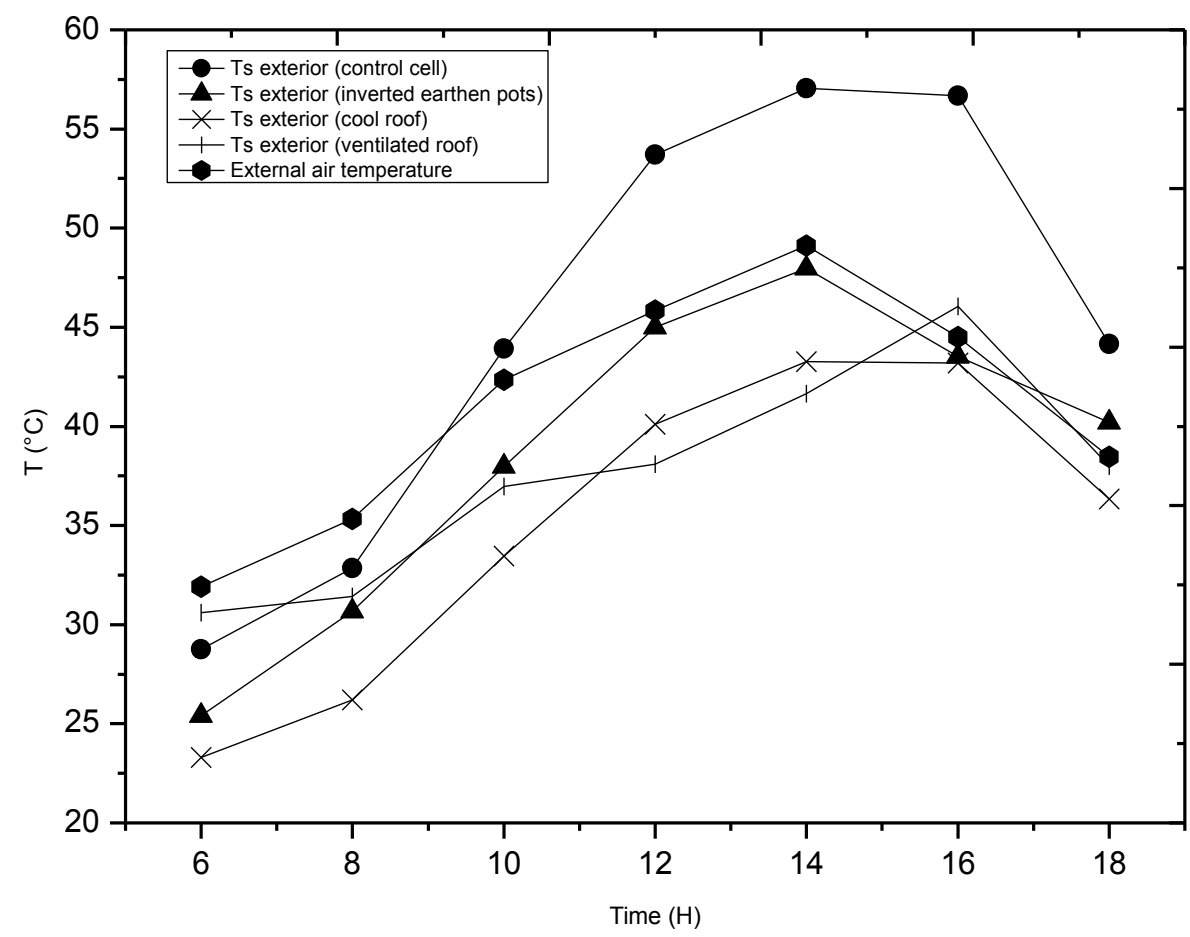

Fig.7. Profiles of average external surface temperatures of test cells during the month of July.

The figure below shows that the values of exterior Ts increase gradually from morning to reach a peak at 14: $00 \mathrm{H}$ when the sun is at the zenith, the rays are perpendicular to the surface of the roof.

At that point, the surface temperatures of the roofs decrease to register their lowest value at 6: $00 \mathrm{H}$. These temperatures variations, which range from $23.30^{\circ} \mathrm{C}$ in the early morning to $56.87^{\circ} \mathrm{C}$ in the afternoon, are due to the properties of the outside surface of the roof.

According to the analysis of the results (Fig.7), C3 (reflective coating) represents the best case compared to the control cell (base case) with an average variance of $10.18{ }^{\circ} \mathrm{C}$, then, noting that C1 which corresponds to the types of roofs actually realized (reference case) represents the worst case.

The structure (C3), shows a low average of surface temperatures (Ts) from $6 \mathrm{H}$ to $10 \mathrm{H}$ with a difference of $3{ }^{\circ} \mathrm{C}$ to $7{ }^{\circ} \mathrm{C}$ and from $16 \mathrm{~h}$ to $18 \mathrm{~h}$ with a difference of $2{ }^{\circ} \mathrm{C}$ to $3{ }^{\circ} \mathrm{C}$ for (C2). This is due to the high thermal emissivity of the white membrane $(\varepsilon=0.90)$ which allows the structure to release the heat stored through the day during the night when the outdoor ambient $\mathrm{T}$ decreases. 
Concerning (C4), the profile of the average outside surface presents a reduction less than the other systems especially during the day from $10 \mathrm{~h}$ to $16 \mathrm{~h}$; this is due to the shape of the earthen pots that leave parts exposed to the sun which increases the absorption of the solar gains by the concrete. Therefore, it is preferable to use a layer of clay that completely shades the surface of the roof.

\subsection{Temperature profiles of interior surface}

The interior surfaces temperature profiles of the cells shown in Fig.8, show that C3 records the lowest internal surface temperature with a difference of 2.53 to $7.98{ }^{\circ} \mathrm{C}$.

Therefore, an average difference of $5.31{ }^{\circ} \mathrm{C}$ compared to reference case (C1). C2 has an interior surface temperature $41.47^{\circ} \mathrm{C}$ with a variance of $3.28^{\circ} \mathrm{C}$ in comparison with $\mathrm{C}$.

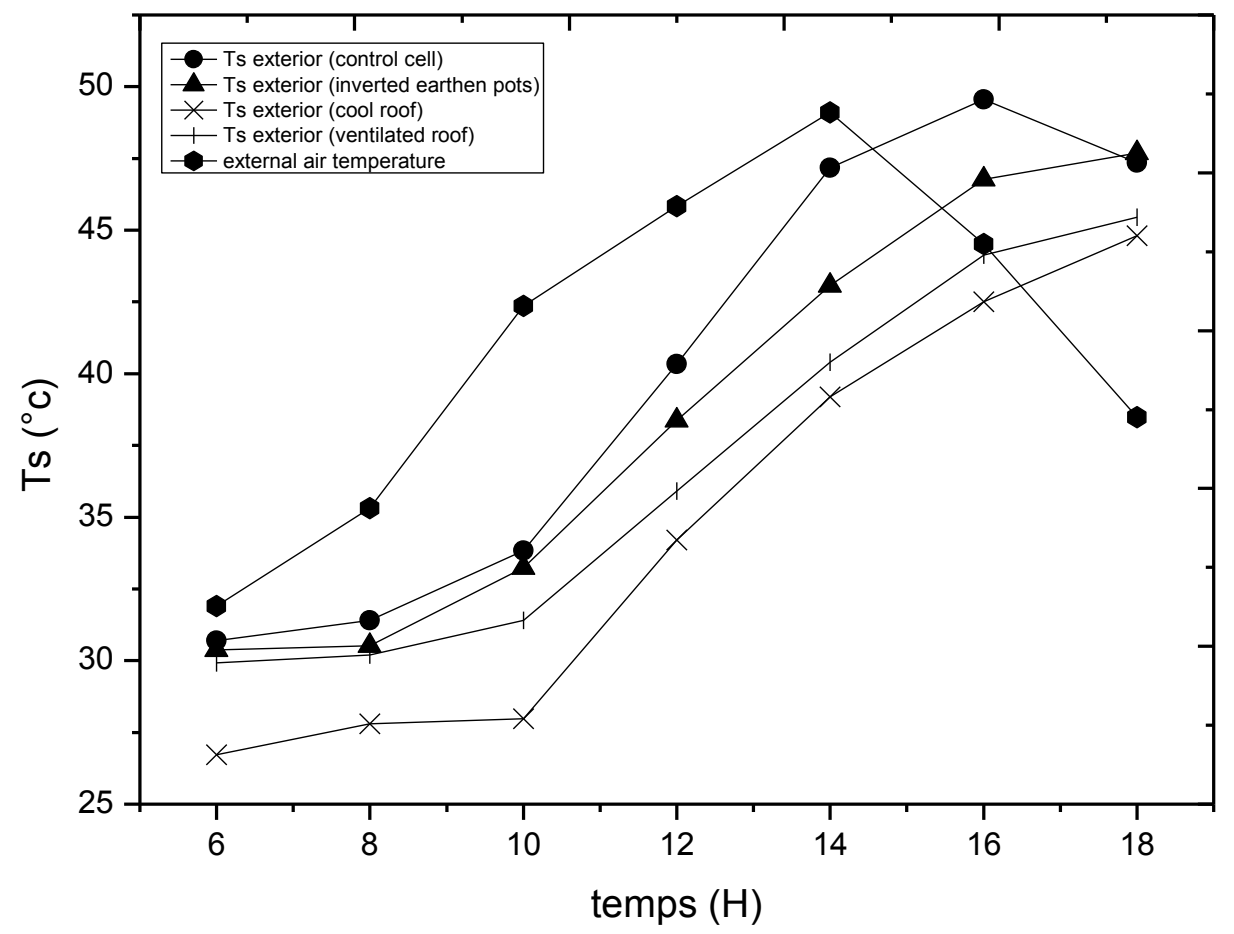

Fig.8. Profiles of the mean lower surface temperatures of the test cells during the month of July.

The thermal behavior of the roofs shown in Fig.8 reveals that the interior surfaces temperature increases with the outside ambient temperature. However, at the end of the day, as the outside $\mathrm{T}^{\circ} \mathrm{C}$ decreases quickly due to the absence of direct solar radiation, the internal surface temperature continues to rise.

This phenomenon is caused by the thermal inertia of the roof which decelerates the passage of the heat waves through the material; the heat absorbed during the day begins to propagate inside the structures which contribute to increase the interior surfaces temperature.

Hence, the application of the "reflecting coating" technique achieves a reduction in the surface temperature which confirming, once again, its effectiveness as a cooling strategy in a hot and arid region. 


\subsection{Interior air temperature profiles}

The use of a high reflectance paint "cool paint" is an effective way to increase the level of comfort inside spaces.

Reading the air temperature profiles inside the structures (ambient T) during the hottest month of the year, exhibited a lowering of the indoor air temperature of $\mathrm{C} 3$ with a variance of $3.33^{\circ} \mathrm{C}$ at $14 \mathrm{~h}$ and $4.80^{\circ} \mathrm{C}$ at $18 \mathrm{~h}$ compared to base case C1 (Fig.9). This situation is explained by a low diffusion of heat inside the cell resulting from the high reflectance $(=0.9)$ and high thermal emittance of material with high radiative properties that protects the roof.

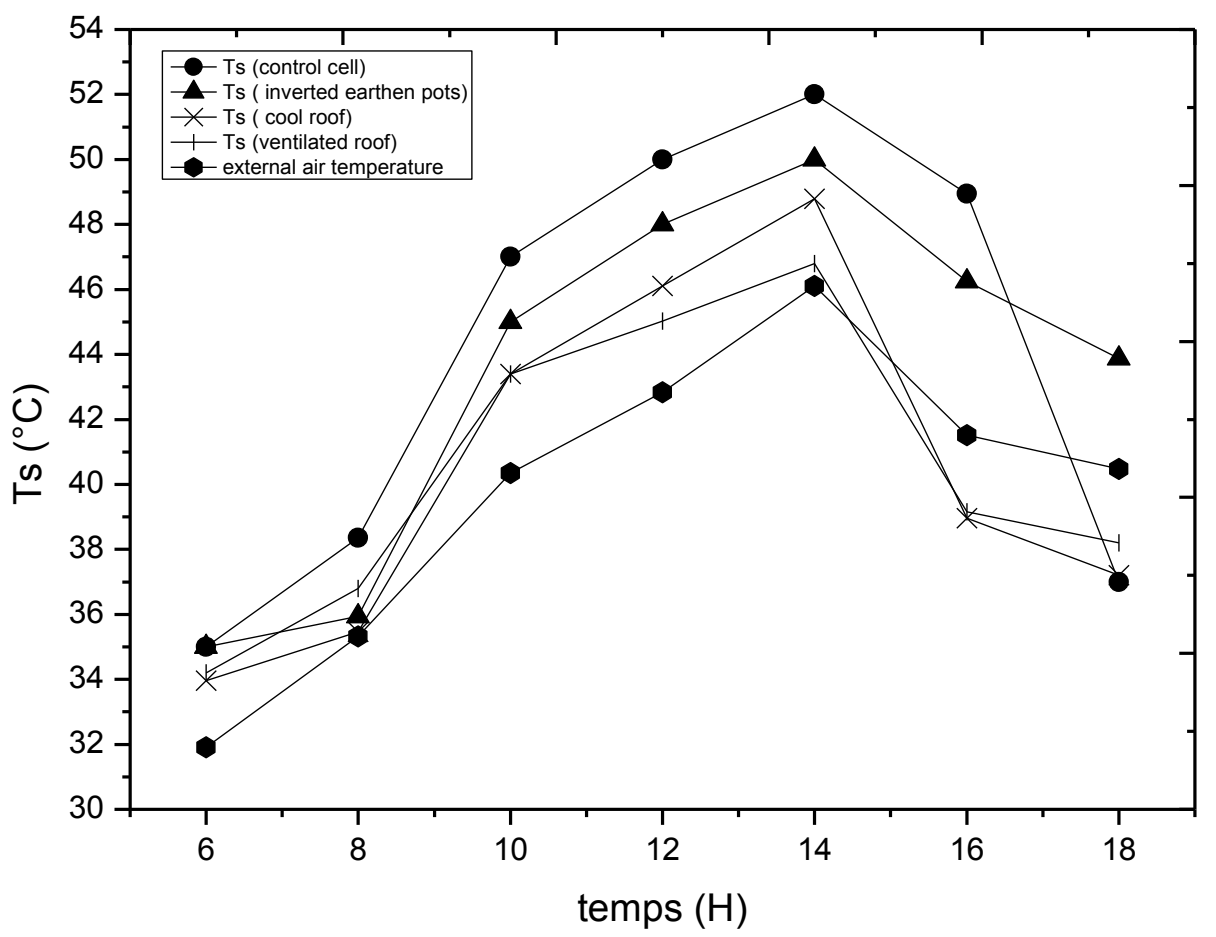

Fig.9. Profiles of mean indoor air temperatures of test cells during the month of July.

Examining the graph of the temperature curves shown in Fig.9, it appears that the $\mathrm{T}^{\circ} \mathrm{C}$ reaches its maximum value $50.20^{\circ} \mathrm{C}$ at $14 \mathrm{~h}$ for $\mathrm{C} 3,53{ }^{\circ} \mathrm{C}$ for $\mathrm{C} 2$ and $\mathrm{C} 4$ at $16: 00 \mathrm{~h}$, when the outside air temperature reaches $38.48{ }^{\circ} \mathrm{C}, \mathrm{C} 1$ records $54{ }^{\circ} \mathrm{C}$. In fact, the heat stored inside takes a long time to begin to dissipate to the outside due to the absence of natural ventilation. The retained information from these results confirms that: the more the roof is reflective, the more the surface temperature is lower, and consequently, more the transfer of heat is slowed down.

\section{Conclusions}

It's agreed that the roof is one of the most difficult parts of the building to protect, because it's the most exposed to direct sunlight. This paper presents the main results of an experimental work consecrate to optimize the thermal performance of the individual houses by applying passive cooling techniques on the roofs under warm and arid climatic conditions of Biskra. The study focused on the evaluation of: 1) the cool roof, 2) the ventilated roof and 3) the reversed earth pots as passive, innovative and inexpensive strategies. The research explored all means to apply these techniques according to the conditions and specificities of the context of the study. The results of the experiment carried out showed that the use of the "cool roof" technique on standard concrete roofs significantly reduced the surface temperature. In addition, the 
ventilated roof, for its part, presents acceptable results if combined with natural ventilation which promotes the fast cooling of the structure.

To conclude, the results obtained have validated by experimentation, the investigations founding this research and demonstrated the effectiveness of the technique of the "cool roof" which has the advantage both of minimizing the thermal stress undergone in buildings and its detrimental effect on health and, at the same time, makes it possible to rationalize energy consumption and preserve the environment.

\section{References}

Akbari, H., Levinson, R., \& Rainer, L. (2005). Monitoring the energy-use effects of cool roofs on California commercial buildings. Energy and Buildings, 37(10), 1007-1016.

Al-Obaidi, K. M., Ismail, M., \& Rahman, A. M. A. (2014). Passive cooling techniques through reflective and radiative roofs in tropical houses in Southeast Asia: A literature review. Frontiers of Architectural Research, 3(3), 283-297.

Amer, E. H. (2006). Passive options for solar cooling of buildings in arid areas. Energy, 31(8-9), 1332-1344.

Bakhlah, M. S., \& Hassan, A. S. (2012). The Effect of Roof Colour on Indoor House Temperature In Case of Hadhramout, Yemen. American Transactions on Engineering \& Applied Sciences, 1(4), 2229-1652.

Balocco, C. (2002). A simple model to study ventilated facades energy performance. Energy and Buildings, 34(5), 469-475.

Bencheikh, H. (2013). Full scale experimental studies of a passive cooling roof in hot arid areas. International Journal of Renewable Energy Technology Research, 2(6), 170-180.

Charde, M., \& Gupta, R. (2013). Annual thermal performance of a hollow roof in combination with a cavity wall and static sunshade: Experimental study of energy-efficient rooms. Journal of Energy Engineering, 139(4), 281-289.

Dabaieh, M., Wanas, O., Hegazy, M. A., \& Johansson, E. (2015). Reducing cooling demands in a hot dry climate: A simulation study for non-insulated passive cool roof thermal performance in residential buildings. Energy and Buildings, 89, 142-152.

Gentle, A. R., Aguilar, J. L. C., \& Smith, G. B. (2011). Optimized cool roofs: Integrating albedo and thermal emittance with R-value. Solar Energy Materials and Solar Cells, 95(12), 3207-3215.

Givoni, B. (1978). L'Homme, l'Architecture et le Climat. Paris, Éditions du Moniteur, 460 p.

Hamdan, M. A., Yamin, J., \& Hafez, E. M. A. (2012). Passive cooling roof design under Jordanian climate. Sustainable cities and Society, 5, 26-29.

Kolokotroni, M., Gowreesunker, B. L., \& Giridharan, R. (2013). Cool roof technology in London: An experimental and modelling study. Energy and Buildings, 67, 658-667.

Lee, S., Park, S. H., Yeo, M. S., \& Kim, K. W. (2009). An experimental study on airflow in the cavity of a ventilated roof. Building and Environment, 44(7), 1431-1439..

Madhumathi, A., Radhakrishnan, S., \& ShanthiPriya, R. (2014). Sustainable roofs for warm humid climates-A case study in residential buildings in Madurai, Tamilnadu, India. World Applied Sciences Journal, 32(6), 1167-1180.

Nahar, N. M., Sharma, P., \& Purohit, M. M. (1999). Studies on solar passive cooling techniques for arid areas. Energy Conversion and Management, 40(1), 89-95.

Nahar, N. M., Sharma, P., \& Purohit, M. M. (2003). Performance of different passive techniques for cooling of buildings in arid regions. Building and Environment, 38(1), 109-116.

Parker, D.S, Barkaszi, S.F., Chandra, Jr. S. \& Beal, D.J. (1995). Measured cooling energy savings from reflective roofing systems in Florida: field and laboratory research results, in Proceeding of the Thermal Performance of the Exterior Envelopes of Buildings. ASHRAE, Clearwater, (4-8), 105115. 
Pisello, A. L., Thiemann, A., Santamouris, M., \& Cotana, F. (2013, June). Analysis of a Cool Roof System for Reducing Cooling Loads and Improving Cooling System Efficiency. In Proceedings of CLIMA2013 International Conf. Prague (pp. 16-18).

Raeissi, S., \& Taheri, M. (2000). Skytherm: an approach to year-round thermal energy sufficient houses. Renewable Energy, 19(4), 527-543.

Santamouris M., Ed. (2001). Energy and Climate in the Urban Built Environment. James and James Science Publishers. London, UK,1, 409.

Santamouris. (2005). Passive cooling of buildings. Advances of Solar Energy, ISES, James and James Science Publishers, London.

Suehrcke, H., Peterson, E. L., \& Selby, N. (2008). Effect of roof solar reflectance on the building heat gain in a hot climate. Energy and Buildings, 40(12), 2224-2235.

Synnefa, A., Santamouris, M., \& Apostolakis, K. (2007). On the development, optical properties and thermal performance of cool colored coatings for the urban environment. Solar Energy, 81(4), 488-497.

Tiwari, G. N., Upadhyay, M., \& Rai, S. N. (1994). A comparison of passive cooling techniques. Building and environment, 29(1), 21-31.

Urban, B., \& Roth, K. (2010). Guidelines for selecting cool roofs. US Department of Energy Building Technologies Program and Oak Ridge National Laboratory.

Zinzi, M. (2010). Cool materials and cool roofs: Potentialities in Mediterranean buildings. Advances in Building Energy Research, 4(1), 201-266.

Zinzi, M., \& Fasano, G. (2009). Properties and performance of advanced reflective paints to reduce the cooling loads in buildings and mitigate the heat island effect in urban areas. International Journal of Sustainable Energy, 28(1-3), 123-139. 